\title{
Consequence of loan loss provisions on earnings management behaviour: A study on the best African commercial banks
}

\author{
T.S. Desta*1 \\ Department of Financial Governance, College of Accounting Sciences, University of South Africa, PO Box 392, Unisa, 0003, \\ South Africa
}

*To whom all correspondence should be addressed

tesfatsions@yahoo.com

\begin{abstract}
This study aimed at analysing the relationship between loan loss provision (LLP) and earnings management in the African commercial banks. The study selected the 11 banks among the 32 best commercial banks as identified by the Global Finance Magazine in 2014. These 11 banks are available online in the Bureau van Dijk Bankscope data and helped observe 10 years (2004-2013, of which 2003 is the base) financial statements, which accounts $34.38 \%$ of the 32 best banks. Accounting data derived from 11 years audited financial statements were used; 110 bank-year observations. A two stage panel regression, partial and pairwise correlation, and independent t-test were applied in order to analyse the relationship between the discretionary LLP (DLLP) and earnings management. Accordingly, the study found that loan to deposit (LD), return on asset (ROA), and earnings before tax and provision (EBTP) significantly influence the DLLP. Besides, banks with high premanaged earnings and well-capital more indulge in the DLLP. The study supports empirical findings on income smoothing and external financing hypotheses, but not the capital management hypothesis. Finally, further research on this topic is recommended, among others, by taking relatively large bank-year observations.
\end{abstract}

\section{Introduction}

Many studies reported that the financial statements (particularly earnings) have been manipulated by managers, called earnings management. Among others, earnings manipulation is defined as "an instance in which a company's managers violate generally accepted accounting principles (GAAP) to favorably represent the company's financial performance" (Beneish, 1999:24). Besides, earnings management was defined as "a strategy used by the management of a company to deliberately manipulate the company's earnings so that the figures match a predetermined target" (Rahman, Moniruzzaman \& Sharif, 2013:23).

Accordingly Das, Vaish and Goel (2012:58) explained that there are many tools used by firms to smooth the income, and loss provision is one of them. Since it does not involve any cash outflow, firms find it a very potential tool for smoothing; since loan loss provision (LLP) is a major accrual under the control of bank managers, it leaves them with a room for income smoothing (Yang, 1999:21); and Anandarajan, Hasan and Lozano-Vivas (2003:46) described that the extant literature indicates that the loan loss provision (LLP) is a tool extensively used for the purpose of risk management, reducing earnings volatility (income-smoothing), enhancing managers' compensation and avoiding capital adequacy regulation.

However, the results of bank income smoothing in the form of managing loan loss provisions vary. Collins, Shackelford and Wahlen(1995), Greenawalt and Sinkey (1988), and Wahlen (1994) found a positive relation between LLP and bank earnings; while Ahmed, Takeda and Thomas (1999) and Beatty, Chamberlain and Magliolo (1995) found no evidence of earnings smoothing (as cited by Ahmed et al., 1999:23; Fonseca \& Gonzàlez, 2008:218).

According to the Global Finance (2014), it has been engaging in selecting top banking performers for the last 21 years- with input from industry analysts, corporate executives and banking consultants. Its criteria for choosing has included growth in assets, profitability, strategic relationships, customer service, competitive pricing and innovative products. It has also considered a poll of Global Finance's corporate readership in order to increase the accuracy and reliability of the results.

Considering the above two financial ratios applied by the Global Finance (i.e. Growth in Assets and Profitability), financial statement users must caution the quality of the data provided by. The aforementioned empirical studies evidenced

\footnotetext{
${ }^{1}$ Dr. Tesfatsion Sahlu Desta, an associate professor at the Mekelle University, Ethiopia, is a postdoctoral fellow at the Department of Financial Governance, College of Accounting Sciences, PO Box 389, 0003, UNISA, South Africa since August 1, 2015, for a period of 12 months. The college provided technical supports for undertaking this research. The author would also like to thank the college staff, particularly, Prof. Christo J. Cronje and Prof. Philna Coetzee for their constructive comments and useful suggestions. Findings, interpretations, and conclusions are solely of the author's opinion and do not necessarily represents the views of the institution.
} 
that bank managers may manipulate their financial statements by using their discretionary power mainly on the loan loss provision for a number of reasons, such as attracting external finance, skipping government regulations and sustaining employment tenure.

Thus, this study found it commendable to undertake further investigations of the relationship between LLP and earnings management in order to 1) further enrich the existing empirical findings and 2) assist users of the company's financial statements, such as the financial analysts, investors, creditors and regulators, to forward dependable advices and decisions. The rest body of the paper is organized mainly into four major sections: review of empirical findings; research methodology; results and discussions and finally, conclusions and recommendations followed by suggestions for further studies.

\section{Literature review}

This section has tried to review empirical evidences on the earnings management and the loan loss provision that are relevant to this study. The details are then presented hereunder as follows.

Healy and Wahlen (1999:368) argued that "earnings management occurs when managers use judgment in financial reporting and in structuring transactions to alter financial reports to either mislead some stakeholders about the underlying economic performance of the company or to influence contractual outcomes that depend on reported accounting numbers." Kang and Sivaramakrishnan (1995:353) further explained that the central issue in empirical studies of earnings management (EMI) is the estimation of the managed component (discretionary accruals) when outsiders observe only the sum of the managed and unmanaged (nondiscretionary) accounting numbers.

In view of this, prior researchers have been undertaking constructive investigations on how managers' practice earnings management. These studies enable researchers to determine factors explaining earnings management and, therefore, to disclose the occurrence of earnings management from the statutory disclosures (i.e. the financial statements) (such as Ahmed et al., 1999; Elleuch \& Taktak, 2015; Fonseca \& Gonzàlez, 2008; Lobo \& Yang, 2001; Wan Mohammad, Wasiuzzaman \& Zaini2011). The empirical findings on loan loss provision (LLP) vis-à-vis income smoothing are, thus, reviewed as follows.

Empirical studies found that there is an association between loan loss provision and earnings management. Ma (1988) found both LLPs and charge-offs are used as mechanisms to smooth earnings; Collins et al. (1995) found that LLPs used as a tool to manage earnings; Greenawalt and Sinkey (1988), after controlling for the characteristics of banks' portfolios and economic environment, concluded that LLPs are used to smooth earnings. Further, regional banks tend to engage in income smoothing using LLPs more aggressively than money centre banks; and Bhat (1996) disclosed that banks that manage earnings and engage in income smoothing using LLPs are characterized by low growth, low book to asset ratio, high loans to deposit ratio, high debt to asset ratio, and low return on assets (as cited by Anandarajan, Hasan \& McCarthy, 2006:13).

Fonseca and Gonzàlez (2008:222-225) reported that loan loss provision is managed for income smoothing, as earnings before tax (EBT) has positive coefficients (statistically significant at the $1 \%$ level); results confirmed different patterns of income smoothing across developing countries as well as between publicly traded and non-publicly traded banks. Das et al. $(2012: 58,66)$ have also revealed that Indian banks involve in income smoothing; the loss provisions in public sector banks are higher than the private sector necessitated, among others, persistent performance; and if a bank reports higher profit in the period $t-1$, the probability of loss provision is quite high in period $t$, suggesting income smoothing.

According to Anandarajan et al. (2003:64), LLPs were used as a tool for avoiding capital adequacy regulation as well as LLPs as a tool for earnings management; Perez et al. (2008:438) established that Spanish banks use generic and specific loan loss provisions to manage earnings and Lobo and Yang $(2001: 235,237)$ confirmed LLP as a major accrual under the control of the bank manager is used to reduce the variability of the earnings series (i.e. Income smoothing).

Wan Mohammad et al. (2011:53-54) portrayed that the loan loss provision is negatively associated with discretionary accruals indicating the possible existence of income decreasing earnings management.

Kanagaretnam et al. (2004:137) found that bank managers use the discretionary component of LLP to reduce the variability in earnings. Besides, Kanagaretnam et al. (2004:880) found bank managers' propensity to smooth income through discretionary loan loss provision (DLLP). DLLP is greater when their premanaged earnings variability is greater.

Zoubi and Al-Khazali (2007:507-508) reported that their findings indicate that managers of banks in the GCC region smooth income via loss provision. The relative ROA of the prior period to the ROA before tax and loss for the current period is a significant factor in determining the amount of loss provision to be charged to the current period.

Anandarajan et al. $(2006: 5,42)$ portrayed that banks in Australia use LLPs to manage earnings; listed commercial banks engage more aggressively in earnings management using LLPs than unlisted commercial banks and earnings management behaviour is more pronounced in the post-Basel period.

Thus, the above literature supports that there is an association between loan loss provision and earnings management. Though there is a different pattern of income smoothing between developing and developed countries' banks; across developed countries; across developing countries; and public 
and non-public traded banks, bank managers use loan loss provision to smooth income variability.

On the other hand, empirical studies also found no association between loan loss provision and earnings management. Wetmore and Brick (1994), with reference to LLPs, found no evidence that LLPs are used as a tool for earnings management and Beattyet al. (1995) found no association between LLPs and earnings management (as cited by Anandarajan et al., 2006:13).

Ahmed et al. (1999:2, 23) found strong support for the hypothesis that loan loss provision is used for capital management; but there is no evidence of earnings management via loan loss provisions.

Elleuch and Taktak (2015:166-167) reported that Tunisian banks have resorted less and less to accounting earnings management through the loan loss provisions, but conversely, real earnings management has been revealed, instead, by the sale of investment securities and the use of debt collection agencies.

To sum up, the results of the above reviewed literature demonstrate that there is no consistent result on whether bank managers use loan loss provision (LLP) for smoothing earnings. It is, thus, worth pursuing further study to analyse whether bank managers use loan loss provision (LLP) for smoothing earnings.

\section{Research objectives and hypotheses}

\section{Research objectives}

The aforementioned empirical studies' reviewed on the banking industry show that:

a) There are inconsistent findings on the relationship between the loan loss provision and earnings management (i.e. Income smoothing) and

b) The empirical studies were carried out in both developed and developing economy institutions. But, the research on earnings management in the African banking industry is almost scant. The study is significantly skewed to the developed countries banking industry.

Besides, the Global Finance has conducted the selection of the best banks for the last two decades by using financial ratios, among others, as a criterion. However, its selection would be adversely affected if there is an association between loan loss provision and income smoothing. The use of loan loss provision for income smoothing results distorted balance sheet and income statement data; distort growth in asset and profitability ratios; and distort the selection of best banks.

Thus, these findings call for further empirical research to further refine the theoretical proposition which stated that the loan loss provision is manipulated in order to smooth the variability of earnings. Kanagaretnam et al. (2004:128) also argued that loan loss provisions (LLP), being one of the largest accruals of banks, can be used in isolation to study such smoothing behaviour.

The study was, thus, carried out 1) to investigate whether the observed African commercial banks reduce earnings variability by managing earnings through the use of discretionary loan loss provision (DLLP) and 2) to confirm whether the findings support the empirical findings.

\section{Research hypotheses}

This study refers to the income smoothing hypothesis. Kanagaretnam et al. (2004) explained that managers of banks have incentives to smooth income to reduce the variability in reported earnings. By reducing earnings variability, bank managers can reduce perceived risk because earnings variability is a key indicator of risk (130-131). Variability of reported earnings is, thus, often regarded as a source of risk for firm valuation. Barth et al. (1995) argued that bank shareholders will require a higher risk premium for the increased risk perceived from a more variable earnings stream (as cited by Kanagaretnam et al., 2004:131).

Loan loss provision (LLP) is merely an accounting adjustment to earnings that do not involve any direct cash outflows. LLP decreases the reported net income, retained earnings, and stockholders' equity. LLP offers a signal to the users of the financial statements about the collectability of the loans and investment (Zoubi \& Al-Khazali, 2007:503). Thus, to smoothen income, bank manager takes action to increase reported income when actual income is low, takes action to decrease reported income when actual income is high, and takes no action to adjust income when it is in line with expectations (Kanagaretnam et al., 2004:130-131). Besides, management underestimates loss provision during low year earnings before tax and provision (EBTP) and overestimate the loss provision during high year earnings. Managers are able to shift earnings among periods to smooth income over time through loss provision. Hence, the income smoothing hypothesis predicts a positive relationship between prior year's earnings and the loan loss provision (Zoubi \& Al-Khazali, 2007:503). Therefore,

$H_{\text {la }}$ : The propensity to decrease earnings by increasing DLLP is high for banks with relatively high pre-managed earnings.

Higher earnings variability results in higher variability in ROA which in return results in increasing perceived risk. If ROA computed on EBTP for this year is higher than last year, then management is expected to increase LLP in order to decrease earnings for the current year. The variability in ROA strongly induces bank managers' smooth income through the LLP. Thus, a positive relationship between LLP and ROA is expected.

$H_{1 b}$ : The degree of income smoothing through discretionary LLP is positively related with ROA. 
Loan to deposit (L/D) ratio measures the relationship between loans and investment to customers' deposits. The higher the $\mathrm{L} / \mathrm{D}$ ratio, the higher the perceived risk (i.e. Earnings variability), and the more will be the need for the external funds. To attract external funds, a bank must reduce the perceived risk via a decrease in the loss provision (Zoubi \& Al-Khazali, 2007:505). In addition, Kanagaretnam et al. (2004:131) argued that the need for external financing is an important incentive for income smoothing. Given that the cost of financing is a function of a bank's perceived risk, bank managers have an incentive to smooth income to reduce large fluctuations. Hence, a negative relationship is expected between LLP and L/D.

$H_{2 a}$ : The degree of income smoothing through discretionary LLP is positively related to the demand for external financing (high $L / D$ ratio).

Since loss provision affects retained earnings, which is part of the stockholders' equity, a higher loss provision results a lower earnings, lower equity, and higher debt-equity (D/E) ratio, a higher perceived risk and, therefore, high-leverage which adversely affects their ability to source external financing. Conversely, lower loss provision will lead to higher earnings, higher equity and lower DE ratio (low risk) (Zoubi \& Al-Khazali, 2007:503). Hence, a positive relationship is expected between LLP and D/E.

$H_{2 b}$ : The degree of income smoothing through discretionary LLP is positively related to the demand for external financing (high D/E ratio).

The regulatory treatment of banks differs cross-sectionally depending on their capitalization levels (Kim \& Kross, 1998, as cited by Kanagaretnam et al., 2004:132). Regulatory actions such as the frequency of examinations and restrictions imposed on the banks' activities will vary depending on how well banks are capitalized. Banks that are viewed by bank regulators as being well-capitalized are less frequently audited and are less subject to intrusive regulatory actions than are banks that are not well-capitalized. This increased regulatory scrutiny of banks with low levels of capitalization (at risk banks) reduces their ability to smooth reported income (Kanagaretnam et al., 2004:132). Besides, capital ratios (CR) above (below) the sample mean total capital ratio as banks that are well (not-well) capitalized (Liu et al., 1997, as cited by Kanagaretnam et al., 2004:132). However, the study used total equity to total assets (EA) as a proxy to the CR because most of the selected banks did not report the CR; rather they reported EA as one of their capitalization ratio.

$H_{3}$ : The degree of income smoothing through DLLP is greater for relatively well capitalized banks than for relatively not-well capitalized banks.

Akin to the capitalization level, banks that are viewed by bank regulators as large are less frequently audited and are less subject to intrusive regulatory actions than are banks that are small. This increased regulatory scrutiny of banks with low total assets reduces their ability to smooth reported income. Larger banks, measured by the natural logarithm of total assets (lento), are expected to afford larger loss provision than smaller banks (Zoubi \& Al-Khazali, 2007:505). Thus, a positive relationship between LLP and $\operatorname{lnTA}$ is expected.

$\mathrm{H}_{4}$ : The degree of income smoothing through DLLP is greater for relatively larger banks than for relatively small banks.

\section{Methodologies}

\section{Sample}

It was intended to address the banking industry in Africa. Among the 32 African banks that were ranked as the "Best Banks 2014: Africa" by the Global Finance Magazine (Global Finance, 2014), only the 11 banks disclosed their 11 years financial statements in an online called Bureau van Dijk Bankscope (Bureau van Dijk Bankscope, 2015; URL:http://www.bankscope.bvdinfo.com/version-

2015831/home.serv). This helps observe 11 years audited financial statements ( 2003 - 2013, where 2003 is a base); that is, 110 bank-year observations (i.e. 11 banks *10years each).

\section{Data analysis techniques}

The data analysis techniques applied by Elleuch and Taktak (2015), Fudenberg and Tirole (1995), Kanagaretnam et al. (2004) and Zoubi and Al-Khazali (2007) were adapted for examining whether the LLP signals earnings management in the selected commercial banks. Panel data for 10 years from 11 African commercial banks was observed (i.e. 110 observations). Two-stage panel regression, correlation, and independent t-test were employed to analyse the income smoothing (earnings management) hypothesis. The first stage panel regression determines the nondiscretionary loan loss provision (NDLLP) as equation 1 depicted below (Elleuch \& Taktak, 2015:158; Kanagaretnam et al., 2004:133):

$$
N D L L P_{i t}=\alpha_{0}+\beta_{1} N P L_{i t-1}+\beta_{2} d N P L_{i t}+\beta_{3} d T L_{i t}+\varepsilon_{i t}
$$

where,

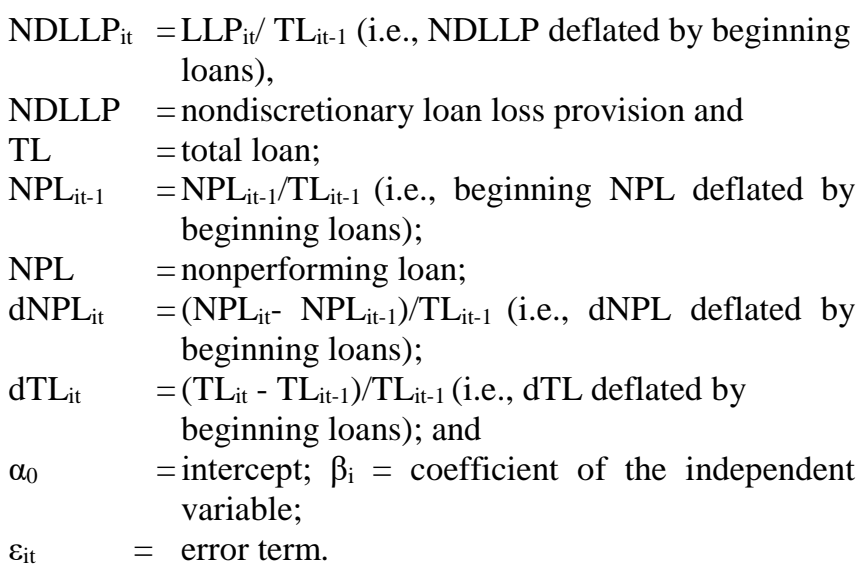

The independent variables account for the NDLLP and their coefficients are expected to be positive. Besides, the discretionary component of LLP (DLLP) is given by the 
residual term of equation 1 above, that is, the bank's LLP as reported in its financial statement less its NDLLP. The second stage panel regression was also carried out in order to test the degree of income smoothing hypotheses through DLLP. The DLLP (residuals) was analysed by employing the following model (Kanagaretnam et al., 2004:135):

$$
\begin{aligned}
& D L L P_{i t}=\alpha_{0}+\beta_{1} L D_{i t}+\beta_{2} E A_{i t}+\beta_{3} E B T P_{i t}+\beta_{4} \ln T A_{i t}+ \\
& \beta_{5} R O A_{i t}+\beta_{6} D E_{i t}+\varepsilon_{i t} \ldots
\end{aligned}
$$

where,

DLLP $_{i t}=$ discretionary component of the provision for loan losses estimated as the residual of equation

(1);

$\mathrm{LD}_{\mathrm{it}} \quad=\left(\mathrm{L}_{\mathrm{it}} / \mathrm{D}_{\mathrm{it}}\right) ; \mathrm{L}=$ loan and $\mathrm{D}=$ deposit;

EA $_{\text {it }}=$ Total Equity to Total Assets; used as a

proxy for CR.

$\mathrm{ROA}_{\mathrm{it}}=\left(\mathrm{EBTP}_{\mathrm{it}} / \mathrm{TA}_{\mathrm{it}}\right)$

$\mathrm{DE}_{\mathrm{it}} \quad=\left(\mathrm{TD}_{\mathrm{it}} / \mathrm{TE}_{\mathrm{it}}\right) ; \mathrm{TD}=$ Total Debt, $\mathrm{TE}=$ Total Equity;

EBTP $_{\text {it }}=\left[\left(\mathrm{EBTP}_{\mathrm{it}} / \mathrm{TA}_{\mathrm{it}-1}\right)\right.$;

$\operatorname{lnT} A_{i t}=$ Natural logarithm of Total Assets; and

$\alpha_{0} \quad=$ intercept;

$\beta_{\mathrm{i}}=$ coefficient of the independent variable;

$\varepsilon_{\text {it }}=$ error term.

LD, DE, lnTA, ROA and EA explain differences in DLLP, that is, they are the factors that are expected to influence income smoothing. They are not factors that sum up the amount of DLLP. DLLP is already computed as the residual of equation 1 . The propensity of income smoothing relates to, among others, the need for external finance, attracting additional investment, escaping from regulatory supervision as well as influencing market prices. Besides, EBTP captures the income smoothing incentive related to pre-managed performance.

\section{Model specification}

The panel regression model was tested for its normality, heteroskedasticity, and serial correlation to check for its model fitness. Its model specification test confirmed that the model is well specified/fit to explain the dependent variable (i.e. The discretionary loan loss provision). Accordingly the results showed that:

- There is heteroskedasticity at $\mathrm{P}<0.05$, tested by the Modified Wald test for group wise; thus, robust fixed effect regression was run.

- There is no serial correlation (autocorrelation) at $\mathrm{P}>0.05$, tested by the Pesaran CD test.

Besides, the Hausman test was made in order to determine whether the fixed effect or random effects regression model is an appropriate model for the panel data at hand. Accordingly, the fixed effect panel data regression was found appropriate and run. The regression diagnostic tests are summarized in Table 1.

\begin{tabular}{|c|c|c|c|c|}
\hline Diagnostic type & Diagnostic test & Decision rule & Diagnostic result & Decision \\
\hline \multirow[t]{2}{*}{$\begin{array}{l}\text { Appropriate model of } \\
\text { panel data regression } \\
\text { (Equation 1) }\end{array}$} & $\begin{array}{l}\text { Step1(Hausman } \\
\text { specification test): } \\
\text { Ho: Random effect } \\
\text { Ha: Fixed effect }\end{array}$ & $\begin{array}{l}\text { Accept Ho if } \mathrm{P} \text { is } \\
\text { not significant, } \\
\text { otherwise Ha. }\end{array}$ & $\begin{array}{l}\text { Chi2 }(3)=1.26 \\
\text { prob }>\text { chi2 }=0.7394\end{array}$ & $\begin{array}{l}\text { There is no evidence to reject the null } \\
\text { hypothesis (Ho). Thus, the random } \\
\text { effect regression is appropriate to } \\
\text { explain the outcome. }\end{array}$ \\
\hline & $\begin{array}{l}\text { Step } 2 \text { (Buresch and } \\
\text { Pagan LM test): } \\
\text { Ho: Pooled regression } \\
\text { Ha: Random effect }\end{array}$ & $\begin{array}{l}\text { Accept Ho if } \mathrm{P} \text { is } \\
\text { not significant, } \\
\text { otherwise Ha. }\end{array}$ & $\begin{array}{l}\text { Chi } 2(1)=3.12 ; \\
\text { prob }>\text { chi } 2=0.0775^{* * *}\end{array}$ & $\begin{array}{l}\text { The null hypothesis (Ho) is rejected, and } \\
\text { the random effect model is found to be } \\
\text { appropriate model to explain the } \\
\text { outcome. } \\
\text { NB: Robust random effect is } \\
\text { regressed in order to eliminate } \\
\text { heteroskedasticity. }\end{array}$ \\
\hline $\begin{array}{l}\text { Appropriate model of } \\
\text { panel data regression } \\
\text { (Equation 2) }\end{array}$ & $\begin{array}{l}\text { Hausman specification } \\
\text { test: } \\
\text { Ho: Random effect } \\
\text { Ha: Fixed effect }\end{array}$ & $\begin{array}{l}\text { Accept } \mathrm{Ho} \text { if } \mathrm{P} \text { is } \\
\text { not significant, } \\
\text { otherwise Ha. }\end{array}$ & $\begin{array}{l}\text { Chi2 }(4)=12.07 \\
\text { prob }>\text { chi2 }= \\
0.0169^{* *}\end{array}$ & $\begin{array}{l}\text { The null hypothesis }(\mathrm{Ho}) \text { is rejected, and } \\
\text { the fixed effect model is found to be } \\
\text { appropriate model to explain the } \\
\text { outcome. }\end{array}$ \\
\hline
\end{tabular}

\section{Table 1: Summary of diagnostic tests}

NB: Robust fixed effect is regressed in order to eliminate heteroskedasticity.

\section{Note:}

Table 1 presents the model diagnostic tests for selecting the appropriate model for running the panel data regression model. First, the random effect model is tested against the fixed effect. The null hypothesis (Ho) is rejected and the alternate hypothesis $(\mathrm{Ha})$ is accepted when $\mathrm{p}$-value is significant, i.e., $\mathrm{p}<0.01$, $\mathrm{p}<0.05$, or $\mathrm{p}<0.10$. Second, when there is no evidence to reject the null hypothesis (i.e., Ho: Random effect), the random effect is further retested against the pooled regression. Then the null hypothesis (Ho: Pooled regression) is rejected and the alternate hypothesis (Ha: Random effect) is accepted when p-value is significant, i.e., $\mathrm{p}<0.01, \mathrm{p}<0.05$, or $\mathrm{p}<0.10$.

$* * 5 \%$ significance level, $* * * 10 \%$ significance level.

\section{Results and discussions}

The Pearson partial correlation, independent t-test, and fixed effect regression results are presented as follows. 


\section{Correlations}

Table 2 presents the partial correlation of the dependent variable (LLP) with the independent variables- NPL, dNPL, and dTL. NPL and dNPL are positive and significantly correlate with the LLP as expected and support the empirical evidences. But, dTL is negative and significantly correlated with LLP, that is, inconsistent with the expectation and the empirical evidences which stated that dTL correlates with LLP positively and significantly (Kanagaretnam et al., 2004).

\section{Table 2: Partial correlations (equation 1)}

\begin{tabular}{l|l|l|l}
\hline Partial correlation of LLP with NPL, dNPL, dTA, sig star(5) & dNPL & dTL \\
\hline Variables & NPL & 0.5636 & -0.2348 \\
\hline Coefficients & 0.2758 & $0.0000^{*}$ & $0.0159^{* *}$ \\
\hline P-value & $0.0044^{*}$ & & \\
\hline
\end{tabular}

Observations $=107$

Note:

$\mathbf{L L P}_{\mathbf{i t}}=$ loan loss provision deflated by beginning total loan; $\mathbf{N P L}_{\mathbf{i t}-\mathbf{1}}=$ beginning non-performing loan deflated by beginning total loan; $\mathbf{d N P L}_{\mathbf{i t}}=\mathrm{change}_{\mathrm{in}}$

NPL deflated by beginning total loan; and $\mathbf{d T L} \mathbf{L}_{\mathbf{i t}}=$ change in total loan deflated by beginning total loan.

Table 2 portrays the partial correlations between the dependent variable (LLP) and the independent variables (NPL, dNPL, and dTA).

$* 1 \%$ significance level, $* * 5 \%$ significance level.

Table 3 also depicts the pairwise correlation of the dependent and independent variables for equation 2. Consistent with the prior research findings, EBTP has positive and significant correlation as well as LD has negative and significant correlation with DLLP. However, the results for EA and $\operatorname{lnT}$ A do not support the empirical findings which stated that EA and $\ln$ TA have positive and significant correlation (Kanagaretnam et al., 2004; Zoubi \& Al-Khazali, 2007). Moreover, there is a high correlation between DE and EA as well as between EBTP and ROA, which is higher than 0.80. As a general rule of thumb, multicollinearity is a problem when the independent variables are highly correlated, $0.90 \geq \mathrm{r} \leq-0.90$, (Pallant, 2007:149). Thus, the study follows an alternative specification test through five iterations as illustrated in the panel regression for equation 2 in Table 5.

\section{Table 3: Pairwise correlations (equation 2)}

\begin{tabular}{|c|c|c|c|c|c|c|c|}
\hline \multicolumn{8}{|c|}{$\begin{array}{lllllll}\text { Pwcorr } & \text { DLLP } & \text { ROA } & \text { EA } & \text { LD } & \text { DE } & \text { EBTP } \\
\text { lnTA, sig star (5) }\end{array}$} \\
\hline VARIABLES & DLLP & ROA & \begin{tabular}{l|l|} 
EA \\
\end{tabular} & \begin{tabular}{l|l|} 
& LD \\
\end{tabular} & $\mathrm{DE}$ & EBTP & $\operatorname{lnTA}$ \\
\hline DLLP & 1.0000 & & & & & & \\
\hline ROA & $\begin{array}{c}0.3640 \\
(0.0001 *)\end{array}$ & 1.0000 & & & & & \\
\hline EA & $\begin{array}{c}0.0623 \\
(0.5235) \\
\end{array}$ & $\begin{array}{c}0.5647 \\
(0.0000 *) \\
\end{array}$ & 1.0000 & & & & \\
\hline LD & $\begin{array}{l}-0.1514 \\
(0.1251) \\
\end{array}$ & $\begin{array}{c}0.0856 \\
(0.3807) \\
\end{array}$ & $\begin{array}{c}-0.0002 \\
(0.9986) \\
\end{array}$ & 1.0000 & & & \\
\hline $\mathrm{DE}$ & $\begin{array}{c}-0.0404 \\
(0.6794) \\
\end{array}$ & $\begin{array}{c}-0.4573 \\
\left(0.0000^{*}\right) \\
\end{array}$ & $\begin{array}{c}\mathbf{- 0 . 9 1 8 1} \\
(0.0000 *) \\
\end{array}$ & $\begin{array}{c}0.0036 \\
(0.9707) \\
\end{array}$ & 1.0000 & & \\
\hline EBTP & $\begin{array}{c}0.3650 \\
(0.0001 *)\end{array}$ & $\begin{array}{c}\mathbf{0 . 9 6 1 9} \\
\left(0.0000^{*}\right)\end{array}$ & $\begin{array}{c}0.4730 \\
\left(0.0000^{*}\right)\end{array}$ & $\begin{array}{c}0.0523 \\
(0.5943)\end{array}$ & $\begin{array}{c}-0.3757 \\
(0.0001 *)\end{array}$ & 1.0000 & \\
\hline $\operatorname{lnTA}$ & $\begin{array}{l}-0.0051 \\
(0.9582)\end{array}$ & $\begin{array}{c}0.1998 \\
(0.0364 * *)\end{array}$ & $\begin{array}{c}0.0440 \\
(0.6483)\end{array}$ & $\begin{array}{c}0.2189 \\
\left(0.0235^{* *}\right)\end{array}$ & $\begin{array}{c}0.0356 \\
(0.7120)\end{array}$ & $\begin{array}{c}0.2133 \\
\left(0.0259^{* *}\right)\end{array}$ & 1.0000 \\
\hline
\end{tabular}

Note:

$\mathbf{D L L P}_{\mathbf{i t}}=$ discretionary loan loss provision; $\mathbf{L D}=$ total loan to total customer deposit; $\mathbf{E A}_{\mathbf{i t}}=$ total equity to total assets (used as proxy for capital ratio); $\mathbf{R O A}_{\text {it }}=$ earnings before tax and provision to total assets; $\mathbf{D E}=$ total debt to total equity; $\mathbf{E B T P}_{\mathrm{it}}=$ earnings before tax and provision deflated by beginning total assets; and $\mathbf{l n} \mathbf{T} \mathbf{A}_{\mathbf{i t}}=$ natural logarithm of total assets.

Table 3 describes the pair wise correlations between the dependent variable (DLLP) and the independent variables (ROA, EA, LD, DE, EBTP, lnTA).

$\mathrm{P}$-value in parenthesis.

$* 1 \%$ significance level, $* * 5 \%$ significance level.

\section{Independent t-test}

Table 4 illustrates the independent t-test for the mean difference on DLLP by EBTPsize, EAsize, and lnTAsize. The independent t-test result indicates that;

- There is a significant mean difference between the banks which have high and low pre-managed earnings $\left(\mathrm{EBTP}_{\text {size }}\right)$, that is, banks with high pre-managed earnings engage more in earnings management through DLLP;

- There is also a significant mean difference between wellcapitalized and poorly-capitalized banks $\left(\mathrm{EA}_{\text {size }}\right)$, that is, banks with high capital engage more in earnings management through DLLP. These two findings support the expectations and empirical evidences which reported the existence of significant mean differences. 
Table 4: Independent T-test

\begin{tabular}{|c|c|c|c|}
\hline \multicolumn{4}{|c|}{ EBTPsize } \\
\hline & Low (i.e., below average) & High (i.e., above average) & \\
\hline Mean & -0.00458 & 0.0038364 & \\
\hline Standard Deviation & 0.0121147 & 0.0123604 & \\
\hline \multicolumn{4}{|l|}{ Observation $=107$} \\
\hline \multicolumn{4}{|l|}{$\mathrm{df}=105$} \\
\hline \multicolumn{4}{|l|}{$t=3.5412$} \\
\hline \multicolumn{4}{|c|}{ Diff $=$ mean $(1)-$ mean $(2)$} \\
\hline \multirow[t]{2}{*}{ H0: $\operatorname{diff}=0$} & Ha: diff $<0$ & Ha: diff $\neq 0$ & Ha: diff >0 \\
\hline & $\operatorname{Pr}(\mathrm{T}<\mathrm{t})=0.9997$ & $\operatorname{Pr}(/ \mathrm{T} /-/ \mathrm{t} /)=0.0006^{*}$ & $\operatorname{Pr}(\mathrm{T}>\mathrm{t})=0.0003$ \\
\hline \multicolumn{4}{|c|}{ EAsize } \\
\hline & Low (i.e., below average) & High (i.e., above average) & \\
\hline Mean & -.0024769 & 0.0041011 & \\
\hline Standard Deviation & 0.0128411 & 0.0120553 & \\
\hline \multicolumn{4}{|l|}{ Observation $=107$} \\
\hline \multicolumn{4}{|l|}{$\mathrm{df}=105$} \\
\hline \multicolumn{4}{|l|}{$t=2.6221$} \\
\hline \multicolumn{4}{|c|}{ Diff $=$ mean $(1)-$ mean $(2)$} \\
\hline \multirow[t]{2}{*}{ H0: $\operatorname{diff}=0$} & Ha: $\operatorname{diff}<0$ & Ha: diff $\neq 0$ & Ha: diff >0 \\
\hline & $\operatorname{Pr}(\mathrm{T}<\mathrm{t})=0.9950$ & $\operatorname{Pr}(/ \mathrm{T} /-/ \mathrm{t} /)=0.0100 * *$ & $\operatorname{Pr}(\mathrm{T}>\mathrm{t})=0.0050$ \\
\hline \multicolumn{4}{|c|}{ lnTAsize } \\
\hline & Low (i.e., below average) & High (i.e., above average) & \\
\hline Mean & 0.0004148 & -0.0003698 & \\
\hline Standard Deviation & 0.0121008 & 0.0136054 & \\
\hline \multicolumn{4}{|l|}{ Observation $=107$} \\
\hline \multicolumn{4}{|l|}{$\mathrm{Df}=105$} \\
\hline \multicolumn{4}{|c|}{$\mathrm{T}=-0.3116$} \\
\hline \multicolumn{4}{|c|}{ Diff $=$ mean $(1)-$ mean $(2)$} \\
\hline \multirow[t]{2}{*}{$\mathrm{H} 0:$ diff $=0$} & Ha: $\operatorname{diff}<0$ & Ha: diff $\neq 0$ & Ha: diff $>0$ \\
\hline & $\operatorname{Pr}(\mathrm{T}<\mathrm{t})=0.3780$ & $\operatorname{Pr}(/ \mathrm{T} /-/ \mathrm{t} /)=0.7559$ & $\operatorname{Pr}(\mathrm{T}>\mathrm{t})=0.6220$ \\
\hline
\end{tabular}

Note:

Table 4 renders the independent t-test (i.e., mean difference test) between the above average and below average size groups. EBTPsize, EAsize, and lnTAsize refer to the mean (average) size of EBTP, EA, and lnTA respectively. The null hypothesis (Ho: There is no significant mean difference between the above and below average groups) is rejected when $\mathrm{p}$-value is significant, i.e., $\mathrm{p}<0.01, \mathrm{p}<0.05$, or $\mathrm{p}<0.10$; otherwise there is no evidence to reject the null hypothesis.

$* 1 \%$ significance level, **5\% significance level.

On the other hand, the t-test reveals that there is no significant mean difference between banks with large and small total assets $\left(\operatorname{lnT} \mathrm{A}_{\text {size }}\right)$ in earnings management through DLLP, that is, against the empirical evidences (Anandarajan et al., 2006; Das et al., 2012; Fonseca \& Gonzàlez, 2008; Kanagaretnam et al., 2004; Zoubi \& Al-Khazali, 2007). Therefore, hypotheses $\mathrm{H}_{1 \mathrm{a}}$ and $\mathrm{H}_{3}$ are accepted, but $\mathrm{H}_{4}$ is rejected.

\section{Panel data regression}

\section{First-stage regression (Equation 1)}

The Hausman test was made in order to determine which panel regression model is appropriate for the first-stage regression. Accordingly, the Hausman specification test determined that the random effect regression is appropriate (Table 1).
According to Table 5, the robust random regression shows that the model is fit and all the coefficients in the model are not equal to zero at $\mathrm{p}<0.01$ (i.e. Prob $>\operatorname{chi} 2=0.005$ ) and the model overall explains the dependent variable (LLP) $33.26 \%$. This indicates that the remaining $66.74 \%$ variation in LLP is explained by other variables not observed in the model, that is, the model is not as such strong to explain LLP.

Besides, the regression result revealed that the three explanatory variables are found to be statistically significant to explain the loan loss provision (LLP) at $\mathrm{p}<0.05$. The non-performing loan (NPL) and change in NPL (dNPL) positively explain the LLP as expected and consistent with the empirical evidences. However, the change in total loan (dTL) explains the LLP negatively, which is against the expectation and prior research findings (Kanagaretnam et al., 2004). 
Table 5: Random effect regression (Robust)

\begin{tabular}{|c|c|c|c|}
\hline \multicolumn{3}{|c|}{$L L P_{i t}=\alpha_{0}+\beta_{1} N P L_{i t-1}+\beta_{2} d N P L_{i t}+\beta_{3} d T L_{i t}+\varepsilon_{i t} \ldots$} & \\
\hline Variable & Coefficient & z-statistics & P-value (i.e., $p>/ z /$ ) \\
\hline NPL (+) & 0.0917924 & 3.39 & $0.001 *$ \\
\hline dNPL (+) & 0.6060164 & 3.56 & $0.000^{*}$ \\
\hline $\mathrm{dTL}(+)$ & -0.0147784 & -1.99 & $0.047 * *$ \\
\hline Prob> Chi2 & $0.005^{*}$ & & \\
\hline $\mathrm{R}^{2}$ (Overall) & 0.3326 & & \\
\hline $\mathrm{N}$ & 11 & & \\
\hline T (Average) & 9.7 & & \\
\hline Observation & 107 & & \\
\hline
\end{tabular}

Note:

$\mathbf{L L P}$ it = loan loss provision deflated by beginning total loan;

$\mathbf{N P L}_{\mathbf{i t}-\mathbf{l}}=$ beginning non-performing loan deflated by beginning total loan; $\mathbf{d N P L} \mathbf{L}_{\mathbf{i t}}=$ change in NPL deflated by beginning total loan; and $\mathbf{d T L} \mathbf{L}_{\mathbf{i t}}=\mathrm{change}$ in total loan deflated by beginning total loan.

Table 5 reveals the panel random effect regression (Robust) on Equation 1. Robust regression was applied to mitigate heteroskedasticity problem.

$* 1 \%$ significance level, $* * 5 \%$ significance level.

This can be seen from two perspectives. The LLP is composed of non-discretionary and discretionary LLP. An increase in total loan apparently increases the nondiscretionary component of the LLP. The likelihood of bank's loan collection may be high, but not $100 \%$, that is, for every increase in total loan, to some extent, there will be an associated risk of uncollectibility which leads to an increase in the non-discretionary part of the LLP. On the other hand, an increase in the total loan entails additional external finance and the discretionary part of the LLP will be reduced in order to make bank earnings attractive for the investors. Nevertheless, the negative effect of dTL on LLP is found inconsistent with the empirical evidences.

\section{Second-stage regression (Equation 2)}

According to the Hausman specification test, the fixed effect regression is determined as the appropriate regression for the second-stage regression (equation 2). Thus, robust fixed effect regression was run in order to address heteroskedasticity problem. However, five iterative alternative specification tests (model 1 - model 5) are done, instead of single regression, because the pairwise correlation (Table 3) shows that there is multicollinearity; that is, the correlation between ROA and EBTP as well as EA and DE is greater than 0.80 .

The five alternative specification test models and the aggregate model portrayed that their degree of explaining the variation in the discretionary loan loss provision (DLLP) ranges from $11.86 \%-17.43 \%$ (i.e. Overall $R^{2}$ ); the model is fitted at $\mathrm{p}<0.05$, that is, all the coefficients in the model are not equal to zero. But, the $\mathrm{R}^{2}$ result shows that the model is not so strong to explain DLLP (Table 6).

Table 6 presents the five models examination of the individual impact of each of the six variables of interest. Accordingly, LD is negative and significant at $\mathrm{p}<0.01$ in all the five alternative specification test models and the general model; ROA is positive and significant at $p<0.10$ in the Model 3; and EBTP is positive and significant at $p<0.10$ in Model 1 and Model 2 consistent with the prior expectation as well as the empirical evidences. Therefore, the study implies that LD, ROA, and EBTP are the variables explaining the variation in the DLLP and they are the variables that influence the earnings smoothing behaviour of bank managers. Bank managers may use their discretionary power to estimate LLP for smoothing income variability as well as minimizing bank's perceived risk resulting from earnings variability.

However, DE, EA, and $\operatorname{lnTA}$ are found to be insignificant in all the five models that are inconsistent with prior expectation and empirical evidences (Anandarajan et al., 2006; Zoubi \& Al-Khazali, 2007). As opposed to loan-to-deposit (LD), debtto-equity (DE) does not support the proposition that the an increase in LLP leads to lesser retained earnings, lesser equity, and higher DE ratio which raises the bank perceived risk from the investor point of view. However, the study confirmed that investors consider the total loan-to-total customer deposit (LD), among others, while reviewing bank's perceived risk. Thus, bank managers are expected to smooth earnings variability through managing DLLP in order to source external finance when there is variation in the LD ratio. The lion's share of total debt is the total customer deposit. Therefore, the valid ratio associated with sourcing external financing, as per this study, is LD other than DE. The bank managers may exercise their discretionary to estimate LLP for attracting cheaper external finance.

In the absence of the capital ratio (CR), the study used total equity-to-total assets (EA) as a proxy for CR. The use of proxy might have an impact on the inconsistent finding, that is, EA is insignificant. Similarly, the natural logarithm of total assets (lnTA) is found to be insignificant. Therefore, invariable and strict regulation of the regulatory bodies up on both small and large banks may discourage bank manager's from exercising their discretion to estimate LLP for capital management.

Finally, based on the above results and discussions, hypothesis $\mathrm{H} 1 \mathrm{a}, \mathrm{H} 1 \mathrm{~b}$ and $\mathrm{H} 2 \mathrm{a}$ are accepted and $\mathrm{H} 2 \mathrm{~b}, \mathrm{H} 3$ and $\mathrm{H} 4$ are rejected. 
Table 6: Fixed effect regression (Robust)

\begin{tabular}{|c|c|c|c|c|}
\hline \multicolumn{5}{|c|}{$D L L P_{i t}=\alpha_{0}+\beta_{1} L D+\beta_{2} E A_{i t}+\beta_{3} E B T P_{i t}+\beta_{4} \ln T A_{i t}+\beta_{5} R O A_{i t}+\beta_{6} D E+\varepsilon_{i t} \ldots$ (2) } \\
\hline \multirow[t]{2}{*}{ Variables } & \multicolumn{2}{|c|}{ Model 1: (Except ROA \& DE) } & \multicolumn{2}{|c|}{ Model 2: (Except ROA \& EA) } \\
\hline & Coefficient & P-value $(\mathbf{p}>/ \mathrm{t} /)$ & Coefficient & P-value (p >/t/) \\
\hline DE (-) & 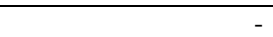 & 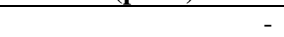 & 0.0001741 & 0.651 \\
\hline ROA (+) & - & - & & \\
\hline LD (-) & -0.0078986 & $0.001 *$ & -0.0076732 & $0.000^{*}$ \\
\hline EA (+) & -0.0541818 & 0.411 & - & \\
\hline $\operatorname{EBTP}(+)$ & 0.226342 & $0.069 * * *$ & 0.2130456 & $0.094 * * *$ \\
\hline $\operatorname{lnTA}(+)$ & -0.0015356 & 0.578 & -0.0016714 & 0.558 \\
\hline \multicolumn{2}{|l|}{$\mathrm{R}^{2}$ (Overall) } & $12.7 \%$ & & $11.86 \%$ \\
\hline \multicolumn{2}{|l|}{ Prob> F } & $0.0143 * *$ & & $0.0182 * *$ \\
\hline \multicolumn{2}{|l|}{$\begin{array}{l}\mathrm{N} \\
\mathrm{T} \text { (average) }\end{array}$} & 11 & & 11 \\
\hline T (average) & & 9.5 & & 9.5 \\
\hline \multicolumn{2}{|l|}{ Observation } & 104 & & 104 \\
\hline \multirow{2}{*}{$\begin{array}{l}\text { Heteroskedasticity (Modified Wald test for group wise } \\
\text { heteroskedasticity) } \\
\text { H0: } \operatorname{sigma(i)\wedge 2~=~} \operatorname{sigma}^{\wedge} \mathbf{2} \text { for all } \mathbf{i}\end{array}$} & Chi2(11) & 477.88 & & 468 \\
\hline & Prob>chi2 & $0.0000^{*}$ & & $0.0000^{*}$ \\
\hline \multicolumn{2}{|c|}{ Serial Correlation (Pesaran's test of cross sectional independence) } & $\operatorname{Pr}=1.1411$ & & $\operatorname{Pr}=1.1562$ \\
\hline \multicolumn{5}{|l|}{ Continued ... } \\
\hline \multicolumn{5}{|c|}{$D L L P_{i t}=\alpha_{0}+\beta_{1} L D+\beta_{2} E A_{i t}+\beta_{3} E B T P_{i t}+\beta_{4} \ln T A_{i t}+\beta_{5} R O A_{i t}+\beta_{6} D E+\varepsilon_{i t} \ldots$ (2) } \\
\hline \multirow[t]{2}{*}{ Variables } & \multicolumn{2}{|c|}{ Model 3: (Except EBTP \& DE) } & \multicolumn{2}{|c|}{ Model 4: (Except EBTP \& EA) } \\
\hline & Coefficient & P-value $(p>/ t /)$ & Coefficient & P-value (p >/t/) \\
\hline DE (-) & - & - & 0.0003685 & 0.382 \\
\hline ROA (+) & 0.3406026 & $0.055 * * *$ & 0.2974383 & 0.107 \\
\hline $\mathrm{LD}(-)$ & -0.0084164 & $0.000^{*}$ & -0.0080759 & $0.000 *$ \\
\hline EA (+) & -0.0969438 & 0.145 & - & - \\
\hline $\operatorname{EBTP}(+)$ & - & - & - & \\
\hline $\ln \mathrm{TA}(+)$ & -0.0012367 & 0.664 & -0.0014895 & 0.612 \\
\hline \multicolumn{2}{|l|}{$\mathrm{R}^{2}$ (Overall) } & $17.20 \%$ & & $15.01 \%$ \\
\hline \multicolumn{2}{|l|}{ Prob $>$ F } & $0.0057 *$ & & $0.0101 * *$ \\
\hline \multicolumn{2}{|l|}{$\mathrm{N}$} & 11 & & 11 \\
\hline \multicolumn{2}{|l|}{$\mathrm{T}$ (average) } & 9.5 & & 9.5 \\
\hline \multicolumn{2}{|l|}{ Observation } & 104 & & 104 \\
\hline \multirow{2}{*}{ 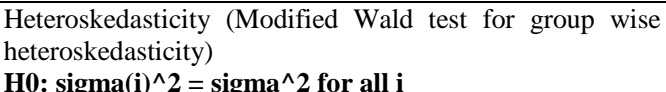 } & Chi2(11) & 412.38 & & 391.82 \\
\hline & Prob>chi2 & $0.0000 *$ & & $0.0000^{*}$ \\
\hline \multicolumn{2}{|c|}{ Serial Correlation (Pesaran's test of cross sectional independence) } & $\operatorname{Pr}=0.6519$ & & $\operatorname{Pr}=0.7835$ \\
\hline
\end{tabular}

Continued ...

\begin{tabular}{|c|c|c|}
\hline \multicolumn{3}{|c|}{$D L L P_{i t}=\alpha_{0}+\beta_{1} L D+\beta_{2} E A_{i t}+\beta_{3} E B T P_{i t}+\beta_{4} \ln T A_{i t}+\beta_{5} R O A_{i t}+\beta_{6} D E+\varepsilon_{i t} \ldots$ (2) } \\
\hline \multirow[t]{2}{*}{ Variables } & \multicolumn{2}{|c|}{ Model 5: Aggregate Model: (includes all the six independent variables) } \\
\hline & Coefficient & P-value $(p>/ t /)$ \\
\hline DE (-) & -0.0008159 & 0.400 \\
\hline ROA (+) & 0.4212139 & 0.135 \\
\hline $\mathrm{LD}(-)$ & -0.0085925 & $0.001 *$ \\
\hline EA (+) & -0.2185559 & 0.152 \\
\hline $\operatorname{EBTP}(+)$ & -0.0602986 & 0.641 \\
\hline $\operatorname{lnTA}(+)$ & -0.0010664 & 0.700 \\
\hline \multicolumn{2}{|l|}{$\mathrm{R}^{2}$ (Overall) } & $17.43 \%$ \\
\hline \multicolumn{2}{|l|}{ Prob> F } & $0.0001 *$ \\
\hline \multicolumn{2}{|l|}{$\mathrm{N}$} & 11 \\
\hline \multicolumn{2}{|l|}{$\mathrm{T}$ (average) } & 9.5 \\
\hline \multicolumn{2}{|l|}{ Observation } & 104 \\
\hline \multirow{2}{*}{$\begin{array}{l}\text { Heteroskedasticity (Modified Wald test for group wise } \\
\text { heteroskedasticity) } \\
\mathbf{H 0 :} \operatorname{sigma(i)\wedge }^{\wedge} \mathbf{2}=\operatorname{sigma}^{\wedge} \mathbf{2} \text { for all } \mathbf{i}\end{array}$} & Chi2(11) & 403.73 \\
\hline & Prob>chi2 & $0.0000 *$ \\
\hline \multicolumn{2}{|l|}{ Serial Correlation (Pesaran's test of cross sectional independence) } & $\operatorname{Pr}=0.3868$ \\
\hline
\end{tabular}

\section{Note:}

$\mathbf{D L L P}_{\mathrm{it}}=$ discretionary loan loss provision; $\mathrm{LD}=$ total loan to total customer deposit; $\mathbf{E A}_{\mathrm{it}}=$ total equity to total assets (used as proxy for capital ratio);

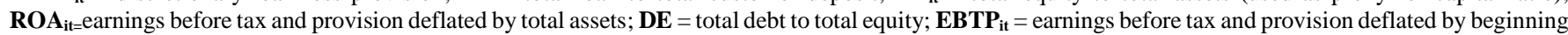
total assets; and $\mathbf{I n T} \mathbf{A}_{\text {it }}=$ natural logarithm of total assets.

Table 6 presents the panel fixed effect regression (Robust) on Equation 2.

Pesaran's test of cross sectional independence revealed that there is no evidence to reject the null hypothesis which says "there is no serial correlation (autocorrelation)" because the probability is insignificant, i.e., $\mathrm{p}>0.05$, for the four alternative specification tests.

Modified Wald test disclosed that the null hypothesis (i.e., residuals are homoskedastic) is rejected and the alternate hypothesis (i.e., residuals are heteroskedastic) is accepted because the probability is significant, i.e., $\mathrm{p}<0.05$, for the five alternative specification tests. Thus, robust fixed effect regression is regressed to mitigate heteroskedasticity problem.

$* 1 \%$ significance level, $* * 5 \%$ significance level, ***10\% significance level. 


\section{Conclusions and recommendations}

\section{Conclusions}

The study examined whether bank specific factor signal income smoothing, capital management, and external financing behaviour of bank managers through the use of their discretionary power on LLP estimation by using secondary data, that is, 10 years bank financial statements (2003 - 2013, where 2003 is a base) observed for 11 banks.

Consequently, the study found that the earnings before tax and provision (EBTP) and return on assets (ROA) positive and significantly influence the discretionary loan loss provision (DLLP); loan to deposit (LD) is negative and significantly influence the DLLP; and total debt to total equity (DE), total equity to total assets (EA), and the natural logarithm of total assets (lnTA) are significant to influence the DLLP. Besides, the independent t-test (mean difference test) depicted that banks with high premanaged earnings (high EBTPsize) and well-capital (high EAsize) may use their discretionary power in estimating LLP; but not the banks with high assets (lnTAsize).

The study, hence, supports the income smoothing and external financing (risk management) hypotheses and conclude that its finding confirms the empirical findings carried on the earnings management. It shows that the banks may regulate their earnings variability through DLLP in order to reduce bank's perceived risk. The bank may increase (decrease) DLLP when the premanaged earnings (i.e. EBTP) is high (low) and loan to deposit ratio (LD) decrease (increase), respectively. However, the study doesn't support the capital management hypothesis. It means the observed banks did not increase (decrease) the DLLP concurrently to the increase (decrease) in their capital. But, this finding is not conclusive. It used total equity to total asset ratio (EA) as a proxy to their capital ratio (CR) because only five out of the 11 observed banks tried to report CR for 11 years. Thus, this necessitates a subject for further research, that is, why banks did not report their capital ratio (Tier 1 and Tier 2).

\section{Recommendations}

The model has proven to replicate in the case of the developed countries as well as the developing countries, including the current study on the African banks. Therefore, based on the research finding, it can be recommended that external stakeholders, including investors and other creditors, may use the discretionary loan loss provision (DLLP) model while assessing the health and soundness of bank's financial statements for making informed as well as a sound decision. The loan loss provision model discussed in this study is found to have an indispensable potential to convey valuable information about bank's earnings management for the benefit of stakeholders, particularly bank regulators, investors and creditors, so that they can make informed sound decisions. Nevertheless, if the model is to be useful, the independent variables that effect the overall loan loss provision (LLP) as well as the discretionary loan loss provision (DLLP) must be carefully selected.

Users of bank financial statements may also be advised to first apply the LLP model in order to verify whether there is no earnings management and the financial data is dependable for decision making before rushing for calculating the financial ratios applicable to the banking industry, such as the CAMEL.

Besides, institutions like the Global Finance are advised to use the mathematical models of efficiency measures, such as the data envelopment analysis or the stochastic frontier, for selecting best banks, other than the financial ratios.

\section{Limitations and suggestions for further study}

The model was not so strong to explain the variation in the DLLP. It explains only to the extent of $17.43 \%$, that is, only three out of six variables explain the variation in the DLLP. Three probable reasons, among others, may be claimed for the weakness of the model: first, as explained above, the absence of the capital ratio (CR) and secondly, minimum bank-year observations that may lead to high pairwise correlation among the explanatory variables as it was actually perceived. The study was limited to 11 banks out of the 32 best African banks as identified by the Global Finance in 2014: some are not on line and others do not have at least a track of 10 years financial reports in the Bankscope data. Some of the inconsistent results with the empirical findings may be due to its small observations (i.e. 11 banks x 10 years $=110$ observations). For example, the numbers of observations made by Ahmed et al. (1999:9), Anandarajan et al. (2003:53), Fonseca and Gonzàlez (2008:217) and Kanagaretnam et al. (2004:132) were 1,013; $970 ; 3,221$; and 25,450 bank-year observations, respectively. Further research is, thus, worth pursuing by considering more observations so that the variability among the independent variables may increase, the multicollinearity may be resolved, and the model will be strengthened.

Besides, the reader should be careful that the analysis did not consider a number of control variables [such as the gross domestic product, asset size, ownership type (i.e. Government or private), and presence of stock market] that may have importance in the determination of the earnings management through the DLLP. Thus, further research can be carried on by controlling the impact of these variables by employing advanced panel data regression.

Finally, the study did not account for and attempt to disclose an actual DLLP management, except for using the identified banks' audited financial statements to test whether the income smoothing hypothesis model (DLLP) and reviewed empirical findings replicate on African banks. By doing so, the study is believed to bridge the existing research gap on the African banks over the DLLP model. 


\section{References}

Ahmed, A.S., Takeda, C. \& Thomas, S. 1999. 'Bank loan loss provisions: a re-examination of capital management, earnings management, and signalling', Journal of Accounting and Economics, 28: 1-25.

Anandarajan, A., Hasan, I. \& Lozano-Vivas, A. 2003. 'The role of loan loss provisions in earnings management, capital management, and signalling: the Spanish experience', Advances in International Accounting, 16: 45-65.

Anandarajan, A., Hasan, I. \& McCarthy, C. 2006. The use of loan loss provisions for capital management, earnings management and signalling by Australian banks. Discussion Papers 23/2006, Monetary Policy and Research Department, Bank of Finland Research, 1-52.

Beatty, A., Chamberlain, S. \& Magliolo, J. 1995. 'Managing financial reports of commercial banks: the influence of taxes, regulatory capital, and earnings', Journal of Accounting Research, 33: $231-262$.

Beneish, M.D. 1999. 'The detection of earnings manipulation', Financial Analysts Journal, 55(5): 24-36.

Bhat, V. 1996. 'Banks and income smoothing: an empirical analysis', Applied Financial Economics, 6: 505-510.

Bureau van Dijk Bankscope. 2015. Bankscope: World banking information source. [online] URL:http://www.bankscope.bvdinfo.com/version-

2015831/home.serv.

Collins, J., Shackelford, D. \& Wahlen, J. 1995. 'Bank differences in the coordination of regulatory capital, earnings and taxes', Journal of Accounting Research, 33(2): 263 - 292.

Das, S., Vaish, A. \& Goel, U. 2012. 'Does loan loss provision signal income smoothing? An empirical investigation of Indian banking industry', IUP Journal of Accounting Research \& Audit Practices, 11(2): 58-68.

Elleuch, S.H. \& Taktak, N.B. 2015. 'Earnings management and evolution of the banking regulation', Journal of Accounting in Emerging Economies, 5(2): 150-169.

Fonseca, A.R. \&Gonzàlez, F. 2008. 'Cross-country determinants of bank income smoothing by managing loan-loss provisions', Journal of Banking \& Finance, 32: 217-228.

Fudenberg, D. \&Tirole, J. 1995. 'A theory of income and dividend smoothing based on incumbency rents', Journal of Political Economy, 103(1): 75-93.

Global Finance. 2014. 'Best banks 2014: Africa', Global Finance Magazine, May $7 . \quad$ [online] URL: http://www.gfmag.com/magazine/may-2014/best-banks-2014-Africa.

Greenawalt, M. \& Sinkey, J.Jr. 1988. 'Bank loan loss provisions and the income smoothing hypothesis: an empirical analysis, 19761984', Journal of Financial Services Research, 1: 301-318.

Healy, P.M. \&Wahlen, J.M. 1999. 'A review of the earnings management literature and its implications for standard setting', Accounting Horizons, 13(4): 365-383.
Kang, S-H. \&Sivaramakrishnan, K. 1995. 'Issues in testing earnings management and an instrumental variable approach', Journal of Accounting Research, 33(2): 353-367.

Kanagaretnam, K., Lobo, G.J. \& Mathieu, R. 2004. 'Earnings management to reduce earnings variability: evidence from bank loan loss provisions', Review of Accounting and Finance, 3(1): 128 148.

Kanagaretnam, K., Lobo, G.J. \& Yang, D. 2004. 'Joint tests of signaling and income smoothing through bank loan loss provisions', Contemporary Accounting Research, 21(4): 843-884.

Lobo, G.J. \& Yang, D. 2001. 'Bank managers' heterogeneous decisions on discretionary loan loss provisions', Review of Quantitative Finance and Accounting, 16: 223-250.

Ma, C.K. 1988. 'Loan loss reserve and income smoothing: the experience in the US banking industry', Journal of Business Finance and Accounting, 15: 487-497.

Pallant, J. 2007. Survival manual: A step by step guide to data analysis using SPSS for windows. $3^{\text {rd }}$ Edition. England: McGrawHill, Open University Press.

Pe'rez, D., Salas-Fumàs, V. \& Saurina, J. 2008. 'Earnings and capital management in alternative loan loss provision regulatory regimes', European Accounting Review, 17(3): 423-445.

Rahman, M.M., Moniruzzaman, M. \& Sharif, M.J. 2013. 'Techniques, motives and controls of earnings management', International Journal of Information Technology and Business Management, 11(1): 22-34.

Wahlen, J.M. 1994. 'The nature of information in commercial bank loan loss disclosures', The Accounting Review, 69(3): 455-478.

Wan Mohammad, W.M., Wasiuzzaman, S. \& Zaini, R.M. 2011. 'Panel data analysis of the relationship between earnings management, bank risks, loan loss provision and dividend per share', Journal of Business and Policy Research, 6(1): 46-56.

Wetmore, J.L. \& Brick, J.R. 1994. 'Loan loss provisions of commercial banks and adequate disclosure: a note', Journal of Economics and Business, 46: 299-305.

Yang, D. 1999. Bank manager's discretion over loan loss provision and determinants of signaling ( $\mathrm{PhD}$ dissertation). Graduate School, Syracuse University, 1-147.

Zoubi, T.A. \& Al-Khazali, O. 2007. 'Empirical testing of the loss provisions of banks in the GCC region', Managerial Finance, 33(7): 500-511. 